\title{
The Malaysian Plot \\ Marcos, Sabah, and the Origins of Moro Secessionism
}

The Lahad Datu incident makes a re-examination of Philippine claim to Sabah compelling. During the twenty-year Marcosian rule, the Sabah claim somewhat defined Philippine foreign policy in its relation to Malaysia and to ASEAN. It was made complicated by the formation of a Moro rebellion. What is the role of Malaysia in the secessionist movement in the south? This article examines this in light of "old" and "new" sources, as it tries to explore a possible conspiracy between Malaysian leaders, the Liberal Party, and some Moro leaders behind the rebellion in Mindanao and Sulu, and its connection to Sabah. 
The recent crisis in Lahad Datu, in which a self-proclaimed Royal Army of the Sultanate of Sulu and Sabah is getting the brunt of brutal military crackdown from Malaysian armed forces, seems to be the long culmination of a bungled attempt in 1968, when a special force was trained only to end in a so-called Jabidah "massacre." It has been forty-five years since the gruesome tale was exposed to the public by the president's father, the late Senator Benigno Aquino, Jr. The son, President Benigno Aquino III, on 18 March, led a commemoration activity in Corregidor Island. But did the bloodbath really take place? Or was it part of a dirty Malaysian scheme to destabilize Mindanao and Sulu so that the Philippine government would postpone, if not to completely withdraw, its claim on Sabah? Was the opposition, the Liberal Party, part of the conspiracy? How did President Ferdinand Marcos deal with the claim before and after the alleged incident? In the present impasse, there are speculations that the standoff is a Malaysian ploy both by the opposition and the present administration that are vying for electoral victory. Are we being taken for a ride by the Malaysians, at the expense of the patrimony of the Sulu Sultanate and the people of Mindanao, victims of foreign intervention that greatly impoverished the region? Can we say that the Moros and their representatives, the Moro National Liberation Front (MNLF), was double crossed by the Malaysians to give up their claim to Sabah in exchange of arms and other support? The information from a number of declassified dispatches from the US embassy in Manila, as released by the US National Archives and corrected by Wikileaks, confirms a number of things on the shady role of Malaysia in fomenting rebellion and supporting the overthrow of President Ferdinand E. Marcos and the diplomatic engagements between Malaysia and the Philippines regarding the claim.

A number of studies had dealt with Sabah, but the discussion centered on its legality and its effect on the conduct of Philippine foreign policy. Noble (1977) examined the Philippine claim to Sabah and concluded that the main reason it was pursued was that Filipinos wanted to assert independence to shake off an image of dependency. Using a comparative perspective, W. K. Che Man (1990) tackled the Moro rebellion in the south, placing it alongside a similar Muslim struggle in Thailand-both were supported by the Malaysiansto generate concepts and ideas on religious and ethnic separatist movements. Azurin (1996) collected his published essays on Muslim struggle in Mindanao, one of which highlighted the improbability 
of "massacre" in the so-called Jabidah hullabaloo. Vitug and Gloria (2000) resurrected the myth of the "massacre," making it appear as though it was the cause of the conflict when it was only the tipping point for a long history of Moro struggle. There were hints and explicit mentions on the Malaysian role in the escalation of the Muslim dissidence in these works, but no one deeply inquired on the longstanding participation of Malaysia in the training of Muslim rebels in the south, from its beginnings to the MNLF and MILF (Moro Islamic Liberation Front) that we know now. This article examines this angle by looking at how Marcos took action on the claim to Sabah as it affected Philippine-Malaysia relations and the resolution of the armed struggle in Mindanao. It re-examines the Jabidah "massacre" and raises the possibility of Malaysian interference even before the creation of a secessionist movement. It suggests ways on how to resolve the claim and the problem in Mindanao and Sulu.

In brief, Sabah was a territory of the Sulu Sultanate that was leased at first to two adventurers who later transferred their rights to a British company. It was a grant of land in 1675 from the Brunei Sultan to the Sulu Sultan for the help in quelling a rebellion (Majul 1999). From 1878 to 1903 , when the confirmatory deed was signed, the area was ruled over by the company until it assumed protectorate status under the British. In 1915, the Carpenter Agreement was signed between the US government and the Sulu Sultan, whereby the latter relinquished his rights to temporal sovereignty, tax collection, and arbitration laws in exchange of an allowance, a lot of land, and recognition as religious leader, without affecting his sovereign rights over Sabah. In 1936, when Sultan Jamalul Kiram II died, the Commonwealth under President Manuel Quezon abolished the Sulu Sultanate, but he recognized the Sultan as religious head; datus and sultan were recognized without official rights and powers. Calling it a deed of cession, the Macaskie decision of 1939 by the High Court of North Borneo rendered a judgment that while the successor-in-sovereignty to the Sulu Sultanate was the Philippine government, the sultan's heirs could claim precedence as to its sovereignty and were entitled to the so-called "cession monies" from the company. After World War II under the Japanese, Sabah was ruled by the British military before Britain illegally made it a crown colony. 


\section{MARCOS AND THE RECOGNITION OF MALAYSIA}

In 1962, President Diosdado Macapagal initiated to claim Sabah when the British relinquished their rights therein for the creation of the Federation of Malaysia (Leifer 1968). Amidst the protests from Indonesia and the Philippines, Malaysia was born on 16 September 1963. The reservations on the result of the UN Ascertainment of September 1963 about the wishes of the people of Sabah to join the federation led Macapagal to not recognize Malaysia and sever diplomatic ties. Malaysia followed suit. In August 1964, consular relations between the two countries were reestablished as agreed upon by Malaysian Prime Minister Tunku Abdul Rahman and Macapagal in Phnom Penh in February 1965, in a series of diplomatic tête-à-tête. According to Macapagal (1968; 1989), Rahman agreed on elevating the dispute to the World Court. Macapagal maintained to not recognize Malaysia, since recognition was seen as tantamount to giving waiver to Malaysia regarding the claim to Sabah. But as the election campaign drew close, Ferdinand E. Marcos, Macapagal's contender to the presidency, dangled the imminent recognition of Malaysia should he win. Marcos won the elections, and a new interesting policy that would direct Philippine ship of state away from stormy seas, albeit temporarily, was to take place during his presidency before the Jabidah mess.

The complete reversal of Philippine policy over Malaysia vis-à-vis Sabah was not simply a matter of political convenience to Marcos. It had to do with the growing smuggling menace in the Southern backdoor, which with Malaysia's help could at least be minimized. The turnaround would entail an arrangement between the two countries. The Philippines would recognize Malaysia in 1966 without prejudice to the claim to Sabah and with, at the same time, an economic and political concession in terms of an anti-smuggling agreement with the latter in 1967. While this compromise had restored at least the regional harmony in Southeast Asia, for fears of harming the interest of the newly-established Association of Southeast Asian Nations (ASEAN) in August 1967-members were trying their best to mediate notably post-Sukarno Indonesia-Marcos's policy with regard to Sabah would change eventually. Such changes will be noted here to unravel the reasons behind the often precarious relationship with Malaysia, marked by insecurity. Of course, the underlying factor would be the Philippine claim to Sabah, which alarms Malaysia should Sabah secede 
and eventually establish an independent state of its own. It turned out that what Malaysia feared to happen did happen in the Philippines, through Malaysia's willful participation in the training and arming of Moro rebels in Sabah, as I shall recount later.

It did not takelong when rapprochement began.Malaysia supported Manila's bid to become the headquarters of the Asian Development Bank (ADB) (Leifer 1968). President Marcos also hinted at this when he stressed in his inaugural address the need to strengthen ties with Asian countries. Then both countries sent notes expressing their desire to raise outposts to embassy level, but it was only in June 1966 that it took effect, with the appointment of ambassadors. Malaysia in a note said that they still recognized their obligations in the Manila Accord of 31 July 1963, including the Joint Statement, and pointed out that particularly paragraph 12 of the Accord and paragraph 8 of the Joint Statement - the recognition did not prejudice the Philippine claim to Sabah and that there should be efforts in settling the claim through peaceful means by negotiation, conciliation, arbitration, or judicial determination - as binding to them. What delayed the recognition was the threat from Sukarno severing ties with Manila should the recognition pushed through (Noble 1977). Marcos was forced to postpone the rites, but when Sukarno was deposed in March, the recognition became imminent as the change of regime welcomed such development.

While Marcos intended to recognize Malaysia since the onset of his presidency, he has never moved away from the official position that the claim must still be pursued. He was bent on tackling the issue of smuggling with Malaysia. It was better to relegate the claim in order to achieve smooth relations with Malaysia after three years of stagnancy. In July 1966, Mr. Peter Lo, the Chief Minister of Sabah, came to Manila to inaugurate Malaysian Airways' first flight to the capital without creating any fuss. Then Malaysia invited the Philippines to send observers to the first direct elections in Sabah to be held in April 1967. It was recommended that two representatives be sent to observe the elections, but with a proviso that such action would not affect the claim. Marcos decided to reject it on the belief that it might prejudice the claim. Another factor was the allegation of Liberal Party Senator Jovito Salonga, that such action would lead the claim to estoppel in international law. Marcos might have also noted the fact that the planned anti-smuggling agreement was not gaining grounds (Leifer 1968). The election did not escape controversy when a tactless 
Philippine consul-general in Singapore aired an unofficial view in a letter to a major daily, that internal security laws prevent the holding of "free" elections (Noble 1977). Malaysia was upset and the diplomat was recalled. Marcos's doubts about the election was confirmed when it took a form of referendum; all candidates favored being federated to Malaysia, and thirty-one out of thirty-two elected assemblymen had platforms rejecting the claim (Quintos 1969). One can see here the beginning of duplicitous conduct by Malaysia, besides the claim that Rahman agreed on settling the dispute in the World Court.

Amidst the silent tension that the mischief has created, there were reports that the government planned a meeting of Philippine and Malaysian representatives in Manila to talk about the settlement of the claim and finally towards a discussion on the mode of settlement. The meeting did not push through. Did Marcos begin to sense that Malaysia was not really willing to settle the dispute? The Manila Accord was signed in July 1963. Four years had lapsed since it was signed, but no headway in the resolution of the claim was visible. And in July, the public admission of Foreign Affairs Secretary Narciso Ramos- that the claim was not in agreement with Article I, section 1 of the Philippine constitution-contributed to the softening of the strain between the two countries. Ramos's admission was to be regarded as indiscretion on his part in exposing the vulnerable side of the claim. The issue on the elections did not deter the two countries, together with Indonesia, Thailand, and Singapore, from establishing the ASEAN in August. Furthermore, Ramos, who went to Kuala Lumpur in September on behalf of the Philippine government, was successful with the signing of anti-smuggling agreement. The agreement contained the expressed permission of Malaysia to the establishment of Philippine liaison customs office in Sempurna, Sandakan, and Tawau in Sabah. The agreement also stipulated on the need for regulating and controlling the trade in Southern Philippines, namely, in Sulu and Zamboanga, and Sabah. Since the country has an outstanding claim on Sabah, a clause was provided in the agreement to guarantee that in spite of the above provisions, it will not affect the territorial claim.

Despite the minor differences relating to the claim, the Philippines tried its best not to engage in any political mishaps that happened in the past which could hurt Malaysian sensitivity. Instead of pursuing a hard-line position towards the claim, political discretion and diplomatic tact mattered in exchange for better relations with Malaysia, although this could be doubted later. The selection committee of the Ramon 
Magsaysay Awards gave the government service award to Malaysia Deputy Prime Minister Tun Abdul Razak for the year 1967, which could not evade a political tinge. In November, Razak visited Manila, which was reciprocated by Marcos and the First Lady in a state visit to Malaysia in January the following year. These conciliatory moves at face value would point to the desire of the Philippine government to stay clear of diplomatic controversies, but nonetheless the motives of Marcos would be questioned later in the course of intriguing revelations.

\section{OPLAN MERDEKA AND THE ALLEGED JABIDAH "MASSACRE": DISSECTING A PSY-WAR OPERATION}

Sometime in September 1967, one Major Abdullatif Martelino, also known as Eddie before he became a Muslim convert, came to Sulu to recruit Tausug men, ages eighteen to thirty (Aquino 1985). $\mathrm{He}$ scoured the Sulu archipelago, taking him four months to undertake the massive recruitment intended allegedly to create a special force of paratroopers after a six-month training and integration to the Armed Forces of the Philippines. He persuaded their elders to let their men join the mission by promising distribution of lands once the secret mission was over. A camp equipped with a radio room was erected in Simunul Island for the purpose of training the said recruits with their uniforms, badges, brand new carbines, and Thompson submachine guns. Although the mission was believed to be a secret, Martelino's dealings betrayed the plan deliberately and everyone in Sulu knew what was happening inside the camp. Recruitment ended in midDecember, and by the end of the month, the 135 enlisted men aboard the Philippine Navy vessel were transported to their new training camp in Corregidor Island. Prior to their arrival, Defense officials visited the campsite and ordered that the old hospital be cordoned off as a restricted area. The old hospital would be the lodging place of the recruits. For the subsequent weeks, they undertook rigorous training in Corregidor jungles. A delay in the release of their allowances caused some of them to petition for redress until they were told to resign if they could not wait. Others were sent home, while the remaining ones engaged in speculations that their co-recruits were killed until it got into their heads that there was a massacre. 
In the wake of these events, Marcos must have initiated, together with some top-ranking defense officials, the setting up of secret paramilitary troops under his command. Was it, as alleged, for the ostensible purpose of freeing a territory? Aquino (1985) related an incident four weeks before his Senate speech-either late February or early March - that a former head of the country's intelligence service told him of a plot contrived by Marcos. Why would a former head tell this highly secret plan to Aquino? Was this former head the chief during the Macapagal administration? Macapagal was a Liberal and so he would only place a Liberal Party member as head of the country's intelligence agency (Macapagal 1968). He was Gen. Marcos Soliman, a classmate and a fellow Kapampangan. The connection becomes clear when one considers Aquino's ethnic affiliation. Why would a former head tell of a government secret that would place the country in jeopardy, except that there was a political motive behind it? When did Marcos take that initiative is a matter of speculation, but the sequence of events give a hint. It took months of planning, but to assume that the planning was under way since probably months after his inauguration is too much. He proceeded to recognize Malaysia and purportedly subordinated the claim in the spirit of regional harmony to the agreement on anti-smuggling. According to US intelligence, Malaysian intelligence service had known since May 1967 that the Philippines was involved in a plot to subvert Sabah (Hughes [1968] 2000). If this claim is true, then Marcos initiated it even before the organization of ASEAN. That the intelligence gathering by the Malaysians was far ahead of the implementation would lead us to conclude that a Malaysian mole had infiltrated the highest echelons of Philippine government.

In the third week of March 1968, a devastating expose shattered the secrecy that had shrouded the plan. It was true that in Sulu the secret mission was widely known, such that the possibility of media exposure was far from nil. Aquino (1985), in his speech, talked about the misgivings of Muslim leaders who told him about what was happening in Sulu, referring to the recruitments and trainings, but this was in the second week of February. Arula came out as the sole survivor of the alleged massacre of Muslim trainees, thereby disclosing to the public the Oplan Jabidah, the code for the project. Arula's testimony recounted the events that led to the supposed massacre. Belonging to the last batch of twelve recruits who were brought to the Corregidor airstrip for the purpose of evacuation, they were ordered to dismount 
their weapons carrier and told to form a line upon reaching the airstrip. They were shot by their military escorts who were armed with highcaliber weapons. With a gunshot wound on his left thigh, Arula ran as fast as he could, until he seemed to see a mountain towards a cliff that brought him to the open sea, clinging to a piece of driftwood when rescued by two fisherman, probably from Cavite (Vitug and Gloria 2000). He sought Governor Delfin Montano of Cavite. There, he divulged the supposed massacre. The governor, a Liberal Party member, called up Liberal Party Congressman Rashid Lucman of Lanao del Sur. Lucman went to Cavite to have a conversation with the survivor.

Opposition leaders capitalized on the controversy to discredit the Marcos administration (Azurin 1996). After his visit to Cavite, Lucman informed Mindanao leaders about the incident, along with Senators Aquino and Gerardo Roxas. Lucman, with Congressman Salih Ututalum, again went to Cavite to cross-examine Arula. After the verification and corroboration of Arula's testimony, which they found it to be credible, the Liberal Party announced the holding of press conference, in which Aquino revealed the alleged massacre, presenting Arula to the public. Marcos was caught red-handed by the opposition. In the heat of the controversy, Lucman filed an Impeachment bill against Marcos. During the congressional hearing on the case, Marcos presented the recruits and said that there was no massacre for they were alive, accusing Arula of being a liar and a paid agent working for the Malaysians. Aquino might have been too hurried to acknowledge the alleged massacre in the press conference, which the Muslim leaders had been taking advantage of in a political showdown with Marcos. Lucman, in a privilege speech, accused the president of conspiring a plot "not only to recover North Borneo [Sabah] by means of infiltration, sabotage and terrorism, but also to create chaos and disorder among the Muslims of Mindanao and Sulu" (as quoted in Azurin 1996, 85). This assumption was not proven since Aquino (1985), in his speech before the Senate, explained why he checked out his scheduled privilege speech a day before. He wanted to verify Arula's testimony as doubt nagged him; to check out the international repercussions and to confirm the story where it started, that was in Sulu.

Aquino's investigation brought some devastating revelations against Arula's testimony, although at times his sworn statement corroborated with the facts of the investigation. "Were they really 'massacred'?" Aquino threw this question before the Senate. A barrage of careful 
deductions followed, in which he underscored why he believed that there was no massacre. He said that this was not a massacre, for there was no "wanton killing of men-maybe premeditated, but definitely committed according to a previous plan." $(1985,55)$. He categorically asserted that there was no plan at all to kill the recruits. He further inquired that if the perpetrators wanted to silence them by bloodbath of sorts, how come they released the twenty-four men, which were believed to have been massacred all along, but were found and met alive and kicking? Arula's testimony was half-lie and half-truth, and the supposed massacre could be the product of a mind exhausted by the paramilitary training and regimen. Instead of a massacre which the probability he said was dim, he submitted that there could have been killings, but these belonged to the criminal category of murder.

There were multiple versions of the reasons why there were killings and why there was the need to set up a secret training camp. The government offered the official version, that the secret training was a counter-insurgency operation to deal with Indonesian communist infiltrators in Mindanao after the overthrow of Sukarno. Some mutinied due to non-release of their monthly allowances and rigorous training, which led to the death of one officer and "a few" recruits (Noble 1977,165). Another version was that of Arula, which recounted that a massacre ensued after a faction of the recruits threatened mutiny over non-payment of their allowances, and he luckily survived and escaped to tell his story about the secret training camp and the plans of sabotage and infiltration in Sabah. Another version, which was different from the two, came from the most controversial figure, Martelino, who testified before the Congressional investigators. Contrary to Arula's version, Project Merdeka was conceived due to intelligence reports that some Muslim warlords were organizing their private armies with the aim of infiltrating and occupying Sabah (Azurin 1996). Its purpose was to avert these groups into doing just that by luring them into joining the secret training, as it aimed to neutralize the private armies' intent of getting into trouble with Malaysia. He also said that by luring them into their secret paramilitary unit, with superior arms and training as a comeon, they had been successful in infiltrating and locating these private armies. They were so successful that the training camp in Simunul could not accommodate the influx of recruits. Corregidor Island became the next stage point, as they were instructed to turn over these recruits to the Philippine Army to give them special training. The first phase of the Project ended on 31 December, and the 
second phase started on 3 January, with a mission different from the first phase.

Aquino did an investigation to verify which one was plausible. According to him, there was indeed a plan to infiltrate Sabah with a "secret strike force" and under the guise of covert crackdown of private armies. Before it could take on its mission, it was apparently sabotaged in the hands of double agents. In Aquino's view, which coincided with Marcos, Arula was a double agent but not necessarily connected to Malaysia, though we cannot overlook this fact (Quijano de Manila 1968). His findings, which found a place in the Philippines Free Press, discounted the tale of a mutiny and massacre, but suggested a more convincing story: that of a divided camp. There was enough evidence to suggest that a struggle ensued between loyalists' faction and faction of mutineers, which implied that the supposed infiltration force was infiltrated by double agents. Was there a hidden Malaysian hand in the disclosure? Reading the mind of Aquino, Azurin (1996) suggested that to Aquino, Arula's story was a staged drama that highlighted a massacre. The detailed unfolding of events in Arula's accounting was highly suspect. Aquino (1985), in his speech, acknowledged that "the counterinsurgency forces of a neighboring country" infiltrated the recruitment in Sulu. The Philippine government, in fact, in a secret reply to a Malaysian note, accused the Malaysians of infiltrating the Philippines from Sabah (Hughes [1968] 2000, 808). From another angle: A Cavite smuggling lord, Montano had a settle to score with Marcos. He was a Liberal that had fallen out of the good graces of Malacañang, which favored a former crony of Montano, Lino Bocalan, also a smuggling lord. Bocalan was said to have financed the recruitment and training in Sulu and Corregidor (Vitug and Gloria 2000). It was not only a rivalry between warlords or smuggling lords that brought the incident to the public (Tiglao 2013a), but it was a clever gambit by the Liberal Party to challenge Marcos, who was gunning for a re-election.

Why did Marcos abort the plan? Did he receive intelligence reports that a leak had been made to the opposition? Soliman, the former NICA chief under Macapagal, was the one who tipped Aquino on the plan. A few weeks later, an international journalist, who was not named, interviewed Aquino. He chitchatted about the plan with him, who also told of an "alarming coincidence that built in his analytical mind, a web of high-octane adventure" (Aquino 1985, 45). The identity of this journalist, possibly white, is again suspicious. Was he privy to 
what was happening in Corregidor? Then Aquino alleged to have pieced together events and was at the point of revealing to the public, when Arula came out of the sanguinary affair. Aquino had known the misgivings of Muslim leaders in the second week of February. Since Martelino was very open on the invasion of some land, the Muslim leaders must have known what this recruitment was intended for. US intelligence alleged that some members of the opposition might have known the secret plan at the outset (Hughes 1968). ${ }^{1}$ By December, the Malaysian operatives had known of guerrillas being trained in Sulu (Hughes [1968] 2000).It would only take somebody from the Malaysian side to contact the Liberal Party in Mindanao and concoct a plan to stage the whole drama of "massacre." This assumption coincides with Azurin (1996, 102-3), who wrote that the secret plan "was apparently sabotaged by double agents who then used it as a launching pad for Bangsamoro secessionism.” If Arula was a Malaysian double agent, he or another double agent could have incited his fellow Muslims to mutiny over non-payment of allowance or over the mission order of inciting rebellion in Sabah. If there was an attempt to kill all the recruits to "conceal the true nature of the mission" as Salonga (2001, 132) put it, why would Aquino find twenty-four trainees in Sulu? The slaughter of the last batches by their superiors must have been caused by the discovery that they were spies, so that the perpetrators were acquitted in the military trial in 1971. Martelino's role was even more mysterious. An undercover agent of Macapagal, he supplied the Liberals with black propaganda materials against Marcos who was running against Macapagal (Aquino 1985). Marcos took him in as head of the Defense Department's Civil Affairs Office and became the chief architect of the Oplan Merdeka. He bungled the affair by letting Arula escape. Was he in collusion with the Malaysians or the Liberal Party? Exonerated from the military trial, he intriguingly went back to Sabah in 1973 and was believed to be dead or languishing in a Malaysian jail (Vitug and Gloria 2000).

The international repercussion of the whole affair, which was publicized widely in local newspapers, included the venting of Malaysian resentment and condemnation over the issue (Noble 1977, 1983). Though red-faced, Marcos, who had visited Malaysia in January, denied these allegations and further declared that war was never a state policy, Rahman warned that trouble between the two countries would come. His threat was apparent as he beckoned his Commonwealth allies, Australia and New Zealand, to deploy their battleships near 
Philippine-Malaysian borders. He accused Marcos of having betrayed his pronouncements. Twenty Filipinos were arrested in Sabah, and Malaysia had linked them up with the incident, saying the weapons confiscated from them were exactly the same used in Corregidor. Were these Filipinos really associated with the failed operation? Were the Malaysians trying to blow the issue out of proportion? The question that arises was how they were able to ascertain that the weapons used in Corregidor were the same as the ones confiscated several days after the alleged massacre. Investigations were ongoing and the public was agog of the news. It only goes to show that Malaysian agents knew more than Filipinos about the incident, or that a spy in pay of the Malaysians was spinning the situation. In fact, the first person who visited the camp was a Caucasian who went ahead of government officials (Azurin 1996). Aquino in his speech did not acknowledge these twenty Filipinos as belonging to the trainees. Six months after the incident, Marcos (1968) revealed in a radio-television chat that there were Malaysian agents roaming in Mindanao and Sulu. Rahman clamored for an international inquiry. The Malaysian government even expressed their concern to the United Nations. Amidst this Malaysian kibitzing, the public, especially the press, stressed that this was an internal affair.

The Philippines responded with an invitation to the negotiating table (Azurin 1996). Salvador P. Lopez, the Philippine Ambassador to the United Nations, challenged Malaysia to let the issue be decided by the World Court, arguing that as long as the Sabah dispute remained unresolved, mutual suspicion and fear would disturb PhilippineMalaysian relations. Malaysia did not accept the challenge. Rahman just contented himself with the conduct of the investigation, expressing high hopes that the issue would find its way to a just solution. In an exchange of notes between April and May 1968, both agreed to hold talks in Bangkok to clarify the Philippine claim, towards discussing the modes of settlement. The controversy served as a wick in the detonation of a political bomb hurled against Marcos by his political adversaries, notably Lucman (ibid.). Lucman charged that the president had personal motive in pursuing Sabah, because the latter had secured the power of attorney, giving the right to get Sabah back through negotiations or other means. The heirs, he said, would give a substantial percentage in the partition of a future settlement for anyone who could return Sabah to them. Not only did he accuse Marcos of having a personal interest in the claim, he also insinuated that Marcos 
was guilty of creating dissensions among Muslims, and asked him if it was his policy, through the AFP, of liquidating his fellow Muslims. This allegation of genocide would appear in the propaganda campaign of the secessionist groups, making it the primary reason why they were taking rebellion against the government, and which found sympathy in the form of direct Malaysian involvement that would subsequently take place.

As the conference in Bangkok was approaching, the press in Sabah was unrelenting in its criticism of the Philippines (Noble 1977). Tun Mustapha, Sabah's Chief Minister, alleged that Kuala Lumpur had been betrayed by Marcos on his promise to not pursue the claim, in exchange for Malaysian help in curbing smuggling. The Sabah finance minister ridiculed the Philippine clamor of bringing the dispute in the World Court, saying that what they could not get through plebiscite, because it would falter, they want to get it through the World Court, and further called on the Sabahans to be vigilant in the midst of possible Filipino infiltrators. Political associations and parties announced their rejection of the claim, and declared that they would be behind any government moves. While Rahman accused Marcos of acting in bad faith, Malaysia, in turn, embarked on directly interfering with the affairs of another nation by fanning the anger of the Filipino Muslims and providing them logistical support for their secessionist dreams. Aquino's speculation that Arula was a double agent, which Marcos also assumed as he accused him of being a paid Malaysian agent, might point to this. Who first did espionage and infiltration between their ranks is not clear, but it might point to the Malaysians, who had contested territory to protect. As the greatest coup in Philippine history as others see it (Tiglao 2013b), the Corregidor "massacre" became the potent vehicle for psy-war by Filipino Muslims in the south to stage their rebellion against the government.

\section{BEFORE AND AFTER THE BANGKOK TALKS: MALAYSIAN INTERVENTION IN SUPPORT OF MORO INSURGENCY}

Prior to the scheduled meeting in Bangkok, Rahman secretly invited Lucman to Kuala Lumpur in May 1968 (Lucman 2010). Rahman, along with Mustapha and Malaysian foreign minister, Ghazali Shafie, told Lucman that they were willing to train Filipino Muslims, about 
10,000 men, who will be supplied with ammunitions, a base, and other logistical support. The trainees would fight for Mindanao's independence to divert the attention of the Philippine government from the Sabah claim. Lucman in June began recruiting ninetytwo Muslims from Moro provinces, and sent them to Sabah for the training to be given by the Malaysian Special Forces. Established on 1 May 1968 by Datu Udtog Matalam, the Muslim—later, MindanaoIndependence Movement (MIM) recruited youths for the training. The Bangkok conference in June and July that would end in failure, as recounted subsequently, was not to be wondered at, given the Malaysian brainchild of instigating an uprising in Mindanao. Shafie's arrogant behavior in the diplomatic table was not surprising too, since the Malaysian side had decided beforehand that there would be no settlement at all, as they wanted the Philippine claim to Sabah to be waylaid by other important - that is, security-concerns.

The first four weeks that started on 17 June was a long quibble on procedural matter, aggravated by technical problems suspected of foul play, delays in the arrival of documents from Manila, and the incompetence of the Philippine delegation (Noble 1977). The Malaysians kept on seeking clarification, which Filipinos found too long and thought would be best to do so in the International Court of Justice. International law expert Florentino Feliciano arrived in the scene, followed by Ambassador to India, Leon Ma. Guerrero. Guerrero, the outspoken nationalist, in a press statement said bluntly: "One of the reasons I've come here is to get to the real point, which is whether the Malaysians are ready to face world opinion in the International Court or whether they intend to persist in this unworthy policy of merely squatting in North Borneo as the forced heirs and puppets of British imperialists and neocolonialists. It appears that behind the Malaysian delegation here there are not only British 'backroom boys,' but the British Navy and the British Air Force, and perhaps the territorials [my italics]" (as quoted in Noble 1977, 172).

The following day, the Philippine delegation decided to put a stop to the clarification and move to discussing modes of settlement. The Malaysian delegation allegedly asked for three more sessions for clarifications. Shafie, who was present in the secret meeting with Lucman, disappointed, rose up and spoke on behalf of his delegation in a long disquisition that the meat and substance of was that the Philippine claim had no legal and political basis and that he was rejecting the claim. The Philippine delegation, the next day, responded 
in two parts. Incensed, Guerrero minced no words that nothing would change their present stand, no matter the length of time devoted to clarification, and questioned the superciliousness of Shafie in rejecting the claim. He declared that the Malaysians "were insincere in these conversations," and said that "to pretend to settle dispute himself and reject the Philippine claim is preposterous, utterly absurd" (as cited in Tolentino 1990, 490). Feliciano talked on the legality of the Philippine claim. To add insult to injury, the Malaysian side even asked the Filipinos if there was anything to discuss before they walked out, according to the deputy prime minister, but what was there to discuss when they had rejected the claim unilaterally. Thus, the talks ended in fiasco after a mouthful of accusations and counter-accusations; Malaysians called Filipinos "cheats," even denigrating the Sulu Sultan as "pirate," to which the Filipinos sought apology (Javier 1968a). While the Philippines might have been sincere in settling the dispute, it was Malaysia, along with their British proxies, that the meeting failed as they were intent on not discussing ways of settlement. In fact, one can say that they deceived the Philippine government from the very beginning; they signed the Manila Accord and the joint communiqué to get Manila's recognition of Malaysia.

The disaster in Bangkok strengthened the resolve of the Philippines to bolster its claim. Back in Manila, the debacle was met with recriminations on the incompetence of the Philippine representatives, saved only by the timely rescue of Guerrero. At first, the Department of Foreign Affairs wanted to withdraw its head of mission in Kuala Lumpur, leaving the embassy in care of an assistant until "a cooling off" period was agreed upon that delayed their complete departure. In view of the loophole in the Tolentino resolution of 1961, which did not include Sabah and raised by the Malaysians in Bangkok, Philippine Congress enacted a law defining the baselines of the Philippine archipelago to include the territorial sea around Sabah (Javier 1968b; Senoren 1968; Patanñe 1968). When it was signed into law in September, Malaysia abrogated the anti-smuggling pact and recalled its ambassador. The so-called "annexation law" fueled angry demonstrations and protests in Malaysia; in Kota Kinabalu, a Marcos effigy was burned (Weekly Nation 1968; Javier 1968c). Demonstrators in Manila centered on the US, British, and Malaysian embassies. A US state department spokesman said that they recognized Malaysia including Sabah. The British were reported to have diverted six RAF Hunter aircraft flying over Sabah, instead of the usual direct flight 
from Hong Kong to Singapore, and that a British commander said that his fleet would be behind Malaysia (Senoren 1968). To rub salt in the wound, the US Air Force allowed British jets bound to Sabah to refuel at Clark Field (Marcos 1977). Marcos was said to have been hurt by US actuations. The Philippines by the end of November would cut its ties with Malaysia, withdrawing its embassy.

The election in both countries was the predominant issue the following year (Noble 1977). The Liberal Party, through Lucman, made the Corregidor "massacre" alive in the election campaign; he secured an affidavit from one survivor, most probably Arula, detailing the "massacre," but the administration denied the claims. The Nacionalista courted one Muslim to run for the Senate. The administration party condemned the Liberal Party's statements as provoking Muslim separatist aspirations. One Nacionalista spokesman reported of massive propaganda on radio from a neighboring country, which was no less than Malaysia, exhorting the people to rebel and aspire for independence, brainwashing them on the abuses committed by the Christian government and extolling the virtues of separate existence or even "annexation," perhaps as part of Malaysia by unlimited opportunities for Muslims as bureaucrats and officials. Rumors that Marcos was targeted for assassination by the Huks were circulating in early November, while the Philippine Constabulary was on heightened alert on 100 Muslims who were trained again in a neighboring country, no doubt Malaysia, and that a Liberal Party politician paid for the Jolo-Cebu tickets of these assassins. The Liberal Party had a bigger role than Lucman's in the creation of a Moro rebellion. Marcos won in Sulu and the whole country, defeating Sergio Osmeña, Jr. He must have known the support by Malaysians given to Muslim groups but decided to keep silent, which was the greatest blunder he committed against the national interest. But was he waiting for the rebellion to happen for his own vested interest? He agreed on restoring relations with Malaysia; Carlos P. Romulo, the new foreign affairs secretary, did the negotiation, so that by 16 December, Rahman announced at the ASEAN meeting the resumption of ties. There was no dropping of the claim, but Malaysian newspapers took it that there was.

Malaysians in collusion with Lucman succeeded in 1970 of training not 10,000 warriors but 28,000 insurgents, ready to do battle against the AFP (Lucman 2000). Nurullaji Misuari, instructor at the state university, took part in the training in Sabah. Aquino welcomed them at Malabang, Lanao del Sur; they were called “Top 90," the first 
batch that would train their fellow rebels (Abbas 2003). Lucmans and Aquinos were old political allies; the former was a founding member of the Liberal Party. The relationship between Lucman and Aquino became close after the Corregidor incident (Lucman 2010). Why would Aquino, a government official, greet the soon-to-be rebels against the government he was sworn to serve, even though he was on the other side of the fence? Was he abetting rebellion in Mindanao? Aquino was privy to what was happening in Sabah and the secret training camp provided by the Malaysians. Through Malaysia, Lucman was able to establish contacts with leaders of the Muslim world. Lucman established the Union of Islamic Forces and Organizations, the umbrella organizations of all national Muslim associations. Malaysia reneged on its promise of arms, which Lucman complained of to the Malaysians. The increased politicization of the Muslims led to the organization of the secret Bangsa Moro Liberation Organization (BMLO) by Lucman, whose timetable for the uprising was moved to 1972, when the Indo-Pakistan War in June 1971 diverted the 2,000 high-powered arms from Libya. The following year, in July, the arms on a plane arrived in Sabah, but the Malaysians had other agenda. Apart from interference, Malaysians legally advocated, not only with their national security in mind but also the Philippine claim to Sabah, the neutralization of Southeast Asia as called for by Tun Abdul Razak, the new Malaysian prime minister, as expressed at the end of the ASEAN Foreign Ministers meeting in Kuala Lumpur in November 1971 (Pathmanathan 1979). The Philippines raised reservations since it would endanger the Sabah claim, because a neutralized state could neither cede nor acquire territory.

In Sabah, Lucman as the founding leader and supreme head of the movement called the chiefs of military units of the Bangsa Moro Army for the distribution of arms. Misuari, Lucman's assistant on military affairs, did not inform the Lanao military heads. He was alleged to have led the killing of Cotabato commanders who were against a planned coup d'état sanctioned by the Malaysians (Lucman 2010). The other side, however, claimed that Lucman and other traditional Moro leaders were planning to use the arms to build their own private armies for their own interests (Santos and Santos 2010). Deceived by the Malaysians, Lucman was made to stay in Kuala Lumpur like a virtual prisoner in a safehouse from October 1972 to February 1973. Marcos had declared Martial Law on 21 September, on the grounds that communist and secessionist movements had placed the republic 
under his command in grave danger. Prior to the declaration, Aquino was flirting with members of Communist Party of the Philippines (CPP) and the New People's Army (NPA), providing them with moral, logistic, and financial support. Less than two weeks before martial law, Aquino in conversation with two US officials "believes that President Marcos intends to stay in power indefinitely and that his own chances of becoming head of the government by legitimate means are slight. He thus may be willing at some point in the future to ally himself with the communists as the leader of a revolution, if he is convinced that this is the best way for him to realize his ultimate political ambition" (as quoted in Claudio 2010). What does this revelation make of the Moro separatism, which he supported? What does this unravel from the alleged Corregidor massacre that the Liberal Party made a big scandal of, and from their relationship with the Malaysians? Aquino's ambition would come to a point when he would sacrifice national interest for his own advantage. In October, an uprising occurred in Marawi, in which 2,000 Muslims were arrested.

According to Lucman, Misuari sold to the Malaysians the arms for the Lanao military unit amounting to P700,000 in 1973 (Lucman 2010). Libyan and Malaysian sympathizers and Misuari divided the proceeds. With Lucman sidelined, Misuari assumed command as chairman of the MNLF, the name he proposed in 1970 that was rejected. Members of the central committee were Abulkayir Alonto as vice-chairman, Jamil Lucman, nephew of Rashid, as chief-of-staff, Hashim Salamat, and others. Misuari was groomed as the leader of the rebellion by the Malaysian press. Why did the Malaysians marginalize Lucman? Were the Malaysians trying to erase from the public mind their participation and Lucman's in the creation of a Moro rebellion by supporting Misuari as the head of MNLF? Were they revising history so as to hide their complicity in the rebellion? Marcos had to engage with Misuari, not Lucman.

\section{GIVING UP THE CLAIM FOR PEACE: MARCOS CONFRONTS THE MNLF UNDER THE PROTECTION OF MALAYSIA}

Aquino before Martial Law was rocking the boat of the détente between Malaysia and the Philippines, when he accused the administration of sending a Filipino secret agent to be arrested and imprisoned in Sabah 
(Noble 1977). Marcos denied the allegation; Malaysia said that no such person was detained in their country, commenting that Aquino's tirade was in bad taste. The government was said to be conducting hushed discussions. From 1973 to 1976, Malaysia continued to provide support to the MNLF through Mustapha, who was a Tausug. Sabah remained to be the training camp, supply and communication depot, and sanctuary for the rebels, and displaced people in Mindanao and Sulu. All these were sanctioned by Kuala Lumpur. On the international level, Rahman was responsible for internationalizing the Moro problem in Mindanao as the secretary-general of the Organization of Islamic Conference (OIC) in 1972 (Che Man 1990). Through Rahman's mediation, the Filipino Muslim rebels gained access to the $\mathrm{OIC}$ and the Muslim community.

Several representatives of Muslim countries visited the country in 1973 to meet with Marcos and agree to possible solutions. In a letter by AFP Chief of Staff Romeo Espino to Marcos, and one of the enclosures in the letter to the US embassy by Romulo, the strength of the so-called Muslim Revolutionary Forces was assessed at 16,900 armed with high powered guns and mortars and supported by Malaysia, Libya, and Pakistan (US Department of State 1973a). Malaysia was now pressuring Marcos to excise from the constitution the article referring to Sabah, but the view of Marcos at this time was it should be Malaysia which should first restore the status quo ante (US Department of State 1973b, 1974c). The following year, in 1974, the MNLF engaged in fierce fight with government troops in Jolo, requiring naval bombardment. The Malaysians succeeded in fomenting a rebellion to take away Sabah from the attention of Marcos administration. The Malaysian government was careful in issuing statements against the claim and dismissed rumors, not because it was convinced of Philippine good intentions, as alleged, but because underneath the pronouncements was the continued interference in Philippine affairs through its support to the rebels. Why did Marcos not press charges against Malaysia before the proclamation of Martial Law? Was he thinking that, in the long run, it would benefit him through the creation of a situation that would force him to declare Martial Law and stay longer in power? Marcos was said to be willing to "forget everything," provided that solutions to the problems related to Sabah could be worked out with Malaysia (US Department of State 1973e, 3). Later the Philippines raised this issue of Malaysian complicity in Southeast Asia Treaty Organization (SEATO) and ASEAN, accusing 
Malaysia of using the Muslim dissidence to blackmail the Philippines in abandoning the Sabah claim (US Department of State 1973f). Romulo, when he went to Kuala Lumpur for the ASEAN foreign ministers meeting, had a talk with Razak in which he pointed out Mustapha's deeper involvement, and that the Sabah ruler, in a meeting in Hong Kong with Osmeña, contributed money to the campaign of the latter in the 1969 elections in return for dropping the claim if Osmeña got elected. Razak lied through his teeth that Malaysia was not involved, but admitted that Mustapha and other Sabahans were.

There were rumors that the Philippine government would give up the claim, provided that Malaysia would stop helping the rebels. When asked about it, Razak denied that Manila made any offer of that kind or that Malaysia had any connection with the Moro insurgency (Noble 1977). There was a planned meeting between Malaysia and the Philippines brokered by Indonesia, but was aborted due to some diplomatic faux pas. The tripartite meeting was moved to 1 June 1973 in Hong Kong, but it failed (US Department of State 1973g, 1973h). The Philippines insisted on getting compensation first for the heirs of the sultan before dropping the claim (US Department of State 1974d). Distrustful of Marcos because they seemed to not get what they wanted, Malaysians wanted a unilateral change in policy on the Philippine side but they never wanted to help defuse the Muslim rebellion in Mindanao and Sulu (US Department of State 1973i). They viewed it as two separate issues when they were not. Indonesia expressed disappointment over Malaysia. Marcos took the perspective that the problem in Sulu was tied to Sabah. For that, he was adopting a two-pronged approach, one that would make a deal with Mustapha, promising him to drop the claim and support for Sabah independence movement, in exchange of non-interference in Sulu and another on the Mindanao problem, which to him was an internal matter (US Department of State 1973j, 1973k).

Razak, in fact, engaged in double talk, for he was said to have told in Islamic meetings that the Moro problem was an internal affair. At the 1974 Islamic Summit in Islamabad, it was him who was said to have demanded that the Moro plight was not an internal affair but a concern for the whole Muslim community (Abbas 2003). Marcos received as early as March 1974 reports confirming that Razak was personally involved in anti-Philippine government activities in Sabah (US Department of State 1974a). He feared that OIC meetings would become a platform in which Razak would influence Arab oil producers 
against the Philippines. If Malaysia desired to dismember Sulu from the Philippines or "some larger scheme" of destabilization, that could be "explosive." He was grateful to Indonesia, but he felt Malaysia frustrated all the efforts and was playing a bigger game with Libya and the Arab states. Mustapha was toying with a Sulu-Sabah state, an independent Sabah or a Sabah joining Indonesia (US Department of State 1974d; Tilman 1976). In early 1974, he sent a personal emissary to Manila for a peace overture, but later repudiated it (US Department of State 1975a). On a visit by a Saudi Arabian minister of state, Marcos succeeded in presenting the Philippine case, carefully documenting Malaysian intervention (US Department of State 1974b). Lahad Datu was identified as one of the training sites, along with Banguey in Sabah. Malaysia denied its involvement and maintained that the Mindanao problem was an internal affair (US Department of State 1974c). Razak was fearful that the Philippines might raise the specter Malaysia created in Mindanao in ASEAN summits (Noble 1977; Quisumbing 1982).

The Penang meeting on 6 May 1974 between Razak and Suharto yielded no optimism, as Malaysia insisted that the Sabah and Muslim conflict were internal to the Philippines, which was pure untruth. Indonesian intelligence had reported of three Malaysian ships trying to ferry arms to Sulu. Marcos and Suharto met at Menado on 29 May on regional issues as well as on Sabah. Prior to this meeting, Marcos was able to set the crowning of a new Sulu sultan, Datu Mohamad Mahakuttah Kiram (US Department of State 1974e). It was in Kuala Lumpur that the June 1974 OIC meeting of the Islamic Conference of Foreign Minister (ICFM) was held, where OIC demanded regional autonomy for the Muslims and negotiations with Bangsa Moro leaders led by Misuari (Che Man 1990; Abbas 2003). The visit of OIC secretary-general in Manila in the same year diminished whatever prospects for negotiation, as it became known to Marcos and his cabinet officials that Misuari allegedly took orders from Libya under the influence of radical Arab Pan-Islamists (US Department of State 1974f).

Marcos sent Alejandro Melchor to head the government panel at the talks held at Jeddah in Saudi Arabia in 1975. He maintained that dropping the claim should first be preceded by willingness of the Malaysian side to cut its involvement with MNLF (US Department of State 1975b). The Middle East talks failed, as the government was not ready to accept autonomy as an option. Since Mustapha did not 
accept the defense portfolio, he had strained relations with Razak, who was moving to isolate him. Mustapha pre-empted Razak from dealing with Marcos by sending his Sabah defense adviser to Manila (US Department of State 1975c). In a reinvestigation of Osmeña/Lopez assassination plot against Marcos, Mustapha was linked to a planned overthrow of Marcos by Osmeña, who was instigating a revolution with Sabah as the base and in connivance with so-called "Sultan" Lucman (US Department of State 1975d). In a visit to Singapore in early 1976, Marcos announced that he will not push for the claim, likening it to a border dispute, which he hoped ASEAN could provide a mechanism for settlement (US Department of State 1976a, 1976b). In the same year, another government panel, headed by Congressman Carmelo Z . Barbero, went to Tripoli to negotiate with the MNLF, resulting in the creation of the Tripoli Agreement. Mustapha was replaced by Donald Stephens in the elections of April, while Hussein Onn took over Razak. Stephens indicated that he would not allow Sabah to be used by the Muslim rebels as base. But the MNLF remained active in Sabah up to the time of Chief Minister Harris Salleh, who replaced Stephens. The Tripoli agreement failed as Marcos scuttled the provisions. The MNLF suffered setbacks when Salamat formed a faction, which was later to become the nucleus of the MILF. If Misuari is to be believed, Malaysia allegedly supported this faction (Pedrosa 2013).

The Moro dissidence continued until the remaining days of the Marcos regime. Marcos, after attending the funeral of Razak in January 1976, went back to Kuala Lumpur in August 1977 for an official visit to attend the Second ASEAN Summit. It was here that Marcos announced that his government would take steps in eliminating one of the burdens of ASEAN: the claim (Republic of the Philippines 1977; Marcos 1977). To Malaysia a draft of agreement on border crossing and joint patrol was handed, which was never signed (Tatad 2000). He told newsmen that dropping the claim would be the key to peace in Mindanao, and realized that if the Philippines had not pursued the claim, there would have been no fighting in the island. Since we have the benefit of hindsight, he was partially correct with respect to Misuari's MNLF on Sabah, but Salamat's faction, as events would later show, was a different matter all together. The Malaysian government had the boldness to ask, if not dictate, that the 1973 constitution be amended and Republic Act 5446 be repealed (Tolentino 1990). The announcement was in keeping with his promise to Onn and Suharto, that he would publicly give up claim after Mustapha is defeated (US 
Department of State 1976d). Onn advised the heirs to take their case in Malaysia for the settlement of their proprietary claims (Quisumbing 1982). It would take another Malaysian prime minister before the heirs would act, when they asked Marcos for direct negotiations with Malaysia (Sindayen 1981). In December 1979, the Philippine government decried the report that Sabah allowed Misuari and his men to have 100 motorboats to smuggle arms and ammunition to Mindanao, and to transport back casualties to Sabah for treatment (Che Man 1990). It was two years previous that Salleh reassured Marcos that Sabah would not offer assistance to MNLF (Republic of the Philippines 1977). Was Mustapha, although ousted from power but still active in politics, the point of contact by the MNLF? MNLF continued to hold conferences there, and the Bangsa Moro Nerws was published in Sandakan until 1981 (Noble 1983). More splits occurred inside the MNLF in 1982.

In 1978, Marcos sent some spies to Sabah, not to regain Sabah as insinuated (Azurin 1996), but to possibly document by photo the activities by MNLF rebels on the island. One of them was caught by a Malaysian agent. Was the plan of getting details of specific sites intended to sow terror in Sabah by agent-provocateurs to get even with the Malaysians? Or would they be used as countermeasure to any plan by the MNLF in collusion with Malaysians? Or was it born out of frustration with Malaysia, which after the signing of the Treaty of Amity and Cooperation in Southeast Asia on 24 February 1976 at Bali, kept on violating the principle of non-interference? During this year, the Malaysian King, Yang di Pertuan Agong, visited Marcos at Malacañang; Onn and Suharto offered to mediate in the Mindanao conflict, but Marcos said that, although help was welcomed, talks with the MNLF would prove difficult, given the factionalism in the group (Foreign Service Institute 1985). In June 1980, Minister of Parliament Arturo Tolentino told the ASEAN Foreign Ministers Conference in Kuala Lumpur that the claim was closed (Quezon 2013). Series of talks broke down, when Malaysia disagreed with the Philippine panel. Several diplomatic engagements were made on the issue in Manila and Kuala Lumpur. Romulo Espaldon, admiral of the Philippine navy, however, claimed in October that Malaysia was cuddling the Muslim rebels by providing training and base camps in Sabah (Samad and Abu Bakar 1992). It was also reported that Malaysian ships and aircraft intruded into Philippine territory. 
Defense Minister Juan Ponce Enrile, in November 1981, alluded to anti-government activities on the same island by members of the Philippine Democratic Socialist Party (Bulletin Today 1981b). Did Sabah become another venue for subversion against the Philippine government? As soon as the news was leaked, the Batasan or the Philippine national legislature reacted by attempting to file a resolution requesting the president to review the position he took in Kuala Lumpur regarding the claim (Dacanay 1982). Marcos was quick to call for silence on the issue, because he said it would affect the ongoing negotiations, although some assemblymen were uneasy over the presidential intervention on Batasan affairs (Valmoria 1981). An assemblyman asserted that since Sabah was Philippine territory, it was outrageous to allow it to become training grounds for rebels. Malaysia had just appointed Mahathir Mohamad as its new prime minister in July 1981. Did he know and sanction the use of Jampiras Island as base for subversive organizations? In December 1981, a speedboat used to ferry arms to the rebels was seized in Mindanao, from which Malaysia denied involvement (Bulletin Today 1981a). A diplomatic faux pas occurred in early 1982, when the Indonesia ambassador, Leo Lopulisa, urged the Philippine government to drop the claim; the latter was "extremely displeased" over the remark and summoned the presumptuous envoy (Bulletin Today 1982; Puyat 1982).

The scene turned complicated when, in April 1982, a documentary aired in Australia, showing that British and Australian mercenaries were involved in the training of Muslim rebels financed by Gaddafi (Samad and Abu Bakar 1992). Were the Malaysian agents named "Mr. George" actually British or Australians? The Malaysians seemed to have the full support of Commonwealth nations, as they were willing to support destabilization. It was through Malaysia that OIC gave its US $\$ 1$ million contribution to the Moro cause until 1996 (Santos and Santos 2010). Despite its open support for the rebels, in November 1982, the Malaysian foreign ministry has the temerity to ask again for the deletion of a clause in the constitution (Quezon 2013). Mahathir pressed for the dropping of the claim, and denied receiving any communication from Marcos regarding the claim (Foz 1982). On the other hand, Solicitor General Estelito Mendoza said that the government was prepared to establish a consulate in Kota Kinabalu, to agree on an international air agreement, and to enter into a border crossing agreement (Sindayen 1982). Minister Roberto V. Ongpin commenced his secret talks with Mahathir, purportedly on Sabah, that 
would continue for the next three years. As revealed recently, Aquino, before his arrival in Manila to be shot in 1983, passed by Kuala Lumpur and talked to Mahathir; he was said to have negotiated that he would drop Sabah in exchange for Malaysia's support for Marcos (Mateo 2013). Having exposed this revelation, could this be part of the motive why he was shot?

The refugee problem in Sabah was, in fact, a creation of Malaysia, contrary to the assertions by Malaysian ambassador that it was a "spillover effect" imposed on his country (Haniff 1989, 177). The economic dislocation in Sulu and Mindanao was felt acutely by Filipino Muslims caught in the middle of the war between the Muslim rebels and the Philippine government. Sabah under Salleh allowed the Filipino immigrants who arrived before 1976 legal status, while those who came after 1976 were considered illegal aliens. During Mustapha's time, Sabah suffered from lack of manpower, and the fleeing Filipinos helped its economy. As early as 1979, however, there were complaints by locals that Filipino refugees were robbing them of jobs and imputing on them the increase in petty thefts (Asiaweek 1979). By 1983, the number of Filipino evacuees in Sabah ranged from 160,000 and 200,000, as a result of a fresh wave of immigrants since 1980 (Che Man 1990). Under Chief Minister Pairin Kitingan, a new policy was instituted in April 1985, when Sabah government implemented stiffer rules on illegal immigration, with the reason that they compete with Sabahans on jobs and threaten national security (Samad and Abu Bakar 1992).

Marcos was ready to negotiate on the claim with Malaysia. On a visit to Brunei during its independence day, the discussion avoided Sabah, but was set after the May elections, which never took place (Shinn 1984; Tatad 2000). The reason might point to the continued support given by the Malaysians to the rebels, that in 1984, the MNLF in Lanao was able to inflict severe losses to the AFP to the amount of P30 million pesos in just three weeks (Lucman 2000). The sporadic attacks of the MNLF in encounters against the government in the last years of Marcos could only mean one thing: that the Malaysians remained to be the conduit for the supply of arms and ammunitions to the Muslim rebels. The case on Sabah became complicated with the entrance of another actor. Redolent of the later Abu Sayyaf, a group of bandits attacked Lahad Datu, robbed a bank and killed eleven Malaysians on 23 September 1985 (Arevalo 1985). In retaliation, four Malaysian gunboats entered Philippine territory, attacked an island in 
the Sulu archipelago, and killed fifty-three Filipinos. Malaysia denied such attacks, but Enrile confirmed that "unidentified" foreign naval ships were seen in the area with flying vessels escorting. After the overthrow of Marcos, many Filipinos would face deportation in Sabah, as a crackdown on "illegal" immigrants would ensue.

\section{CONCLUSION}

History is a weapon. Fear history, said Andres Bonifacio, whose sesquicentennial birth anniversary, will be celebrated this year. Why should we fear history with respect to Sabah? It is because it disentangles the knots behind so many unexplained actions. It provides the weapon to anyone willing to shape correct policies in pursuit of national interests. History can be viewed in multifarious angles and perspectives. In my point of view, Sabah could be seen as one of the many invisible cogs in Philippine postwar history, one that has had more influence than any other issues in foreign and national affairs of the country. It led to the clamor for independence of Mindanao by Filipino Muslims due to the Jabidah "massacre." It was used as a major campaign issue by the Liberal Party against Marcos. The claim encouraged Malaysia to intervene in the south. The Moro rebellion and the communist threat were two factors, along with greed for power, that forced Marcos to declare Martial Law. Malaysian interference since 1968 fueled the escalation of Moro rebellion through Lucman and, later, MNLF. The peace negotiations continued long after the MNLF suffered from factionalism, first in MILF, a Maguindanao splinter group that is now negotiating with the government, and the old guard and new ones. Failure to resolve the Muslim armed struggle deepened the class and ethnic divisions in the south. While Mindanao's economy deteriorated, Sabah's, although least developed among the states of Malaysia, fared better.

Sabah and its ramifications may surprise or even shock some, for it became the bombshell that pitted Marcos and the Liberal Party. It was also a fodder for the insatiable ambition of Ninoy Aquino in his quest for the presidency. His exposé nearly imperiled Marcos and his chances of winning a second-term. The supposed massacre was turned into a propaganda material for the Muslim separatism. It invited the intervention of Malaysia in Philippine affairs. Aquino supported the rebellion in Mindanao against the government, a patent treason he also 
did when he made contact and even encouraged the CPP-NPA. He was willing to surrender Sabah to court Malaysia on his fight against Marcos. Marcos and Aquino were made for each other; the former, in his lust for power, wanted to protect the status quo from the latter, who wanted it wrested through violent means because of his ambition to lead the country. Can we say Marcos is more patriotic than Aquino, or was Ninoy more heroic than Macoy? In light of these, is Ninoy really a hero? The excesses of martial law could have been forgiven, when economic development trickled down to the poor and spelled genuine economic prosperity. All these were happening in the midst of Moro secessionism and communist insurgency, two movements that Ninoy has dipped his hands into. On the other hand, Malaysia after the 1969 ethnic riot and communist movement in North Kalimantan, did not face serious insurgency, except that it supported one to serve as diversion from Sabah. We are still paying the high price of Malaysian intervention that made Sulu one of the poorest provinces in the country.

It is time to end the Malaysian plot to keep Sabah away from its real owners. Playing with great powers, the Sulu Sultanate was itself caught in a great power rivalry among Spain, Germany, and Britain, and between Britain and the United States. Sulu surrendered its sovereignty over its territory, including Sabah, on 22 July 1878 to Spain. When a royal charter was granted to the British North Borneo Company in 1881, Spain protested but later relented. In the Protocol of 1885, Spain renounced its claims over North Borneo, while in the boundary convention of 1930, Sabah was seemingly not included as part of Philippine territory, so that the 1935 Philippine Constitution would define the national territory on this and the other earlier treaties. The boundary convention, however, did not consider that the sultanate had come under US sovereignty, so that by 1935, upon the establishment of the Commonwealth, Sabah was implicitly placed within Philippine territory. Article III of the protocol was ambiguous, one with an intention to deceive, that Spain renounced all her claims "over the territories of the continent of Borneo, which belong, or which have belonged in the past to the Sultan of Sulu [my italics]." Political realities may have forced the sultanate to waive its sovereign authority to Spain and the US, hoping perhaps either of the two could bring it back as the patrimony of its people. The US was not able to do so, and Filipino nationalists like Quezon seemed to have ignored the claim. Heir to the British imperialists, the Malaysians kept on ignoring 
that what they claimed as theirs is only a property leased, or if they want ceded, in perpetuity from the Sulu Sultanate administered by the British, whose sovereignty remained in the sultan before it was annexed illegally in 1946. The Atlantic Charter of which Britain was signatory in 1941 stated that they "seek no aggrandisement, territorial or other." But five years later, the North Borneo cession order was promulgated. The principle of self-determination cannot be invoked without first settling the proprietary claims of the sultanate and the sovereign rights of the Philippines. Neither the reason of effective sovereignty as the basis of Malaysian possession (Othman 1970) could take precedence over the titular rights of the Sulu Sultanate and, later, Philippine government as the bestower of that sovereignty.

The dissolution of the Sulu sultanate by virtue of acts and treaties, as well as the enactment of the basic law of the land, made the Philippine government the successor-in-sovereignty to Sabah, while its proprietary rights are reserved for the heirs of the sultan. Instruments revoking the lease in 1957 and stipulating cession in 1962 signed by Sultan Muhammad Ismail Kiram are redundant. The revocation of the cession to the Philippine government in 1989 by the present sultan was not only unwarranted but devoid of any legal basis. He has no sovereign power to do that. If "lease in perpetuity" in international law means ninety-nine years, then Sabah had reverted back to the Philippines in 1977 (Ramos 1968, 15). Hong Kong was ceded, not leased, in perpetuity; Britain returned it to Beijing in 1997 after ninety-nine years. When Marcos decided to withdraw the claim on that year, he did not know that the lease had expired. From 1977 up to present, technically, the Philippines owned Sabah as part of its territory, because it did not renew the lease. Deportations made by Malaysia since 1977 were and are therefore illegal and acts of aggression against Philippine sovereignty. Malaysia, without surrendering Sabah or negotiating another contract in 1977 with the Philippine government, is illegally occupying Sabah, deserving their expulsion from the land by any means. Seen in this light, the Lahad Datu incident is an unjust provocation on the side of Malaysia that should have been met with strongest military action by the Philippine government. In theory, the Philippines and Malaysia are in state of war due to the illegal occupation of Sabah since 1977.

Thus, it is farcical why Malaysia is kept in the peace process with the MILF as the "impartial" and "disinterested" third party. The continuation of armed struggle in Mindanao, which it supported, is in 
keeping with its national interest to sidestep the resolution of the claim. The MILF has no interest in Sabah, while Misuari has realized lately that Sabah should be included as part of the resolution of the conflict. He was formerly part of the conspiracy, as he himself acknowledged in an interview with Al Jazeera, to derail the settlement of the claim (Pedrosa 2013). The Malaysian devious tactic was consistent. Lucman was deposed. Misuari was groomed to be known as the founder of the separatist movement, the MNLF. When negotiation with Philippine government was reached, a faction developed within the MNLF through MILF. If Misuari is to be believed, his MNLF faction fell out of the good graces of Malaysia, for suspicion that MNLF would turn against them. Misuari belongs to the Sama Cabingaan ethnic group but is usually known as Tausug. He grew up knowing the Sulu Sultanate and its claim on Sabah, as his great ancestor was allegedly one of the many warriors who joined the campaign to suppress the rebellion in Brunei. Salamat, founder of MILF, was a Maguindanaoan; he has no stake on the claim. MILF has issued a press statement that it would not meddle into Sabah (Free Malaysia Today 2013). Al-Haj Murad Ibrahim said in an interview with a Malaysian daily that with the coming of peace in Mindanao, he expects that Filipino immigrants in Sabah would return to their homeland, when Sabah was part of their homeland, most especially to the Tausugs, Bajaus, and Samas (New Straits Times 2013). Dealing with the MILF rather than MNLF tilts the balance in favor of the Malaysians, who wanted at all costs to deny the claim from the Tausugs and the Philippine government.

What is to be done? Peace process should not be rushed. Malaysia must get out of the negotiating panel. The Philippine government must censure, in strongest terms, the role of Malaysia in fomenting rebellion in Mindanao, and that it must stop supporting rebels in the region. Other countries (Britain, Australia, New Zealand, Libya, Saudi Arabia) must also be warned. Britain deserves to be reproached for failing to honor the contract and for reneging its obligations by passing it to Malaysia. Like a conceited imperialist, it ignored the earlier moves of the Philippine government. What Sukarno and Macapagal feared as a British neocolonial design in Malaysia, happened in the long run with the phantom of Sabah hovering over the land. In a latest unverified report, the US seems to have a hand in the Lahad Datu episode in connivance with the Malaysian opposition, which is willing to support an autonomous Sabah to make way for an American base in that area in return for US support in the upcoming elections (The Mole 
2013). It might be a part of US geopolitical strategy of containing China, and this might provide the reason why the American modern naval ship got stuck in Tubbataha reef. The Philippine government must be very cautious for any sly move by the US and the Malaysian politicians that may compromise the claim to Sabah. It was the height of folly when Cory Aquino government became hostage to Malaysia's national interest, since the Constitutional Commission agreed to take out certain phrases in the provision on national territory. Where in the world can you find a foreign entity dictating to a sovereign country what is to be done with its basic law? Looking back, the recognition of Malaysia was the biggest diplomatic blunder that the Philippine government did. In retrospect, the plan to invade or infiltrate Sabah is justified in the name of Philippine national interests. If it took its course, it may have drastically changed Philippine history. If Malaysia keeps on pursuing its present policy of denying our claim, it is only by force of arms that we can get back Sabah.

Abubakar (2000), to whose memory this article is dedicated, singled out the exclusion of Sabah in peace negotiations, cited the continuing identification of Sulus with Sabah, that during the prime of the sultanate was a lucrative trading area, and called for its inclusion in any peace deal. Sabah is left out of the recently signed framework. Manangkayan, the local name of the Spratly Islands, was within the territory of the Sulu Sultanate. Should it not be included in any final peace agreement to bolster our claim against China's? It is also out of tune with the constitution. The charter did not stipulate the creation of a substate or state. The complete revision of the constitution, providing for an improvised political system, not necessarily federal but indigenous, not only for the Muslims and the Igorots but for all other ethnic groups and their underdeveloped regions, could solve the problem. I suggest the revival of the Sulu Sultanate with limited ceremonial powers. Its restoration would put an end to the numerous claimants to the throne that is becoming pathetic. The present predicament favors Malaysia, because it can use the issue to downplay the claim or to further divide the Tausugs by bringing one to its side. A permanent and long-lasting resolution is needed, not in a piecemeal fashion as the framework is, not only toward the Muslims but to all marginalized Filipinos, victims of Manila imperialism. Any peace deal with the Moros must be preceded by the consolidation of all Muslim militant and rebel groups into one cohesive organization to once and for all end the endless splits that happened and will happen in the 
future. The future of all Muslims hangs on their ability to unite in spite of ideological, class, and ethnic differences. First, we must recognize the true colors of Malaysia as the one that caused the subordination of the claim and the disunity among Muslims, and its dishonest pretensions to peace, to begin the next paces toward the self-determination and development of the peoples of Mindanao, Sulu, and Sabah.

As a footnote to why Marcos did not comply with his 1977 pronouncement of dropping the Sabah claim, Minister of Foreign Affairs Arturo M. Tolentino (1990) related the following that happened in 1984: "Before I made that statement at the ASEAN summit, the Malaysian Prime Minister and I had a private talk. We agreed that as a quid pro quo for the announcement I was going to make, that he would see to it that Sabah would cease to be a training ground for rebels in Mindanao as a departure point for arms smuggling into the Philippines. These promises have not yet complied with, and so we cannot as yet comply with our commitment." Marcos was steadfast in his approach to Sabah since 1973: that Malaysia must first disengage from supporting the Moro rebels before giving in to their demands. Although he was an astute, even wily, foreign affairs tactician, he erred in the selection of men who could have successfully executed his plan to invade Sabah, and was unable to anticipate and prevent Malaysian intervention. What he wanted to happen in Sabah, occurred in Mindanao and Sulu, thus becoming his headache in the years to arrive. The question remains, however: was there really an intention to subvert Sabah and provoke war, or was this part of a psy-war strategy by Marcos to pressure Malaysia to the negotiating table? If there was no Arula, could there have been a successful resolution of the Sabah claim? I doubt it.

\section{NOTES}

1 I wish to express my gratitude to Amy Reytar and Rebecca L. Collier of the US National Archives and Records Administration (NARA) for their assistance in accessing this particular reference. 


\section{REFERENCES}

Abbas, Macapanton Y, Jr. 2003. Is a Bangsa Moro state within a federation the solution? Ateneo Law Journal 48(2): 291-368.

Abubakar, Asiri. 2000. Bangsa sug, Sabah and Sulus' quest for peace and autonomy in Southern Philippines. Ph.D. dissertation, University of the Philippines-Diliman.

Aquino, Benigno, Jr. 1985. A garrison state in the make and other speeches. Manila: Benigno S. Aquino, Jr. Foundation.

Arevalo, Vic. 1985. Attacked by Malaysians? 53 reported dead in Tawi-Tawi raid. Bulletin Today, 1 Oct.

Asiaweek. 1979. Refugees: Quiet crisis in Sabah. 10 Aug.

Azurin, Arnold M. 1996. Beyond the cult of dissidence in southern Philippines and wartorn zones in the global village. Quezon City: UP Center for Integrative and Development Studies and UP Press.

Bulletin Today. 1981a. No complaint yet - Malaysia. 3 Dec.

---. 1981b. Reaffirm close ties between RP, Malaysia. 5 Dec.

---. 1982. CPR deplores Sabah comment. 10 Jan.

Che Man, W. K. 1990. Muslim separatism: The Moros of Southern Philippines and the Malays of Southern Thailand. Quezon City: Ateneo de Manila University Press.

Claudio, Lisandro. 2010. Ninoy networked with everyone, Reds included. GMA News Online: Special Reports, 18 Aug. Online, http://www.gmanetwork.com/news/ story/198820/news/specialreports/ninoy-networked-with-everyone-reds-included, accessed 27 Mar. 2013.

Dacanay, Alex. 1982. New rules to the Sabah game. Who, 16 Jan.

Foz, Vicente B. 1982. Ask RP to drop claim formally. Bulletin Today, 16 Nov.

Foreign Service Institute. 1985. Diplomatic agenda of Philippine Presidents. Manila: Foreign Service Institute.

Free Malaysia Today. 2013. MILF won't meddle in Sabah conflict. 6 Mar. Online, http:// www.freemalaysiatoday.com/category/nation/2013/03/06/milf-wont-meddle-insabah-conflict/, accessed 3 Apr. 2013.

Haniff, Datuk Emam Mohammad. 1989. Malaysia-Philippine relations. Foreign Relations Journal 4(4, Dec.): 174-83.

Hughes, Thomas L. (1968) 2000. Doc. 363: Intelligence note from the director of the Bureau of Intelligence and Research (Hughes) to Secretary of State Rusk. Foreign Relations of the United States, 1964-1968, vol. 26, Indonesia; Malaysia-Singapore; Philippines. Washington: United States Government Printing Office.

--- 1968. Intelligence Note 226, 21 Mar. In File DEF 6-5 PHIL, Central Foreign Policy File, 1967-1969, Box 1612, General Records of the Department of State, Record Group 59, US NARA.

Javier, Ben. 1968a. Sabah talks impasse: World Court out, mediation in? Examiner, 1 Jul.

- - .1968b. Exercise in map making. Examiner, 14 Sep.

---.1968c. Malaysia getting hurt. Examiner, 7 Sep.

Leifer, Michael. 1968. The Philippine claim to Sabah. Switzerland: Inter Documentation Ag Zug.

Lucman, Norodin Alonto. 2000. Moro archives: A history of armed conflicts in Mindanao and East Asia. Quezon City: FLC Press, Inc.

---. 2010. Will Noynoy Aquino be the hero of Muslims in Mindanao? Philippine Star, 20 Aug.

Macapagal, Diosdado. 1968. A stone for the edifice: Memoirs of a president. Manila: Mac Publishing House.

---. 1989. The Philippine claim to Sabah. Foreign Relations Journal 4(4, Dec.): 160-73. 
Majul, Cesar Adib. 1999. Muslims of the Philippines. Quezon City: University of the Philippines Press.

Marcos, Ferdinand E. 1968. Pursue Sabah by peaceful means. Remarks on radio-television chat, Manila, 22 Sep. 1968.

---. 1977. Breaking the stalemate: Towards a resolution of the Sabah question. Manila: National Media Production Center.

Mateo, Janvic. 2013. Ninoy vowed to drop Sabah claim to get KL support vs Marcos. Philippine Star, 13 Mar.

The Mole. 2013. Blowing the whistle on Opposition involvement in Sabah crisis. 3 Apr. Online, http://www.mole.my/content/blowing-whistle-opposition-involvementsabah-crisis, accessed 3 Apr. 2013.

New Straits Times. 2013. Bangsamoro people will return to homeland. 20 Jan. Online http://www.nst.com.my/nation/general/bangsamoro-people-will-return-tohomeland-1.204367, accessed 3 Apr. 2013.

Noble, Lela Gardner. 1977. Philippine policy toward Sabah: A claim to independence. Tucson, AZ: the Association for Asian Studies by the University of Arizona Press.

-- 1983. Roots of the Bangsa Moro Revolution. Solidarity 4(97): 41-50.

Othman, Mohammed bin Dato. 1970. The Philippine claim to Sabah: Its historical, legal and political implications. Kuala Lumpur: Oxford University Press.

Patanñe, E. P. 1968. Sabah's back in the news. Weekly Nation, 9 Sep.

Pathmanathan, Nurugesu. 1979. Conflict management in Southeast Asia: A neutralized Malaysia? In Readings in Malaysian Foreign Policy, comp. and ed. Nurugesu Pathmanathan, 1-31. Kuala Lumpur: University of Malaya Cooperative Bookshop Ltd.

Pedrosa, Veronica. 2013. Nur Misuari: "We had to fight for it." A/Jazeera, 20 Mar. Online, http:// www.aljazeera.com/programmes/talktojazeera/2013/03/201331421944766446. html, 5 Apr. 2013.

Puyat, Christie. 1982. Statement on Sabah clarified. Bulletin Today, 11 Jan.

Quezon, Manuel, III. 2013. North Borneo (Sabah): An annotated timeline 1640s-present. Philippine Daily Inquirer, 2 Mar. Online, http://globalnation.inquirer.net/66281/northborneo-sabah-an-annotated-timeline-1640s-present, accessed 27 Mar. 2013.

Quijano de Manila (Nick Joaquin). 1968. Operation Might? Jabidah? Merdeka? Philippines Free Press, 16 Apr.

Quintos, Rolando. 1969. The Sabah question: Prospects and alternatives. In Symposium on Sabah, 63-82. Manila: National Historical Commission.

Quisumbing, Purificacion Valera. 1982. The Sabah dispute and the ASEAN Amity Treaty. Batas at Katarungan 1(1, Feb.): 70-117.

Ramos, Narciso R. 1968. The Philippines brings the Sabah dispute to the U.N. Text of statement delivered before the 125 member-nations of the United Nations General Assembly during its 23rd Session, New York, Tuesday, 15 Oct.

Republic of the Philippines. 1977. Official Gazette 73(36), 9 Aug. and 5 Sep.

Salonga, Jovito R. 2001. A journey of struggle and hope: The memoir of Jovito R. Salonga. Manila: UP Center of Leadership, Citizenship and Democracy, and Regina Publishing.

Samad, Paridah Abd and Darusalam Abu Bakar. 1992. Malaysia-Philippine relations: The issue of Sabah. Asian Survey 32(6): 554-67.

Santos, Soliman M., Jr. and Paz Verdades M. Santos. 2010. Primed and purposeful: Armed groups and human security efforts in the Philippines. Geneva: Small Arms Survey, Graduate Institute of International and Development Studies.

Senoren, Samuel V. 1968. Sabah: Poisonous banana. Examiner, 5 Oct.

Shinn, John L. III. 1984. An update on the Sabah claim. Malaya, 18 Jun.

Sindayen, Nelly. 1981. Direct talks on Sabah claim. Bulletin Today, 5 Dec.

1982. Stand on Sabah reaffirmed. Bulletin Today, 15 Nov.

Tatad, Francisco S. 2000. Guarding the public trust: The making of public policy. Quezon City: Raya Books. 
Tiglao, Rigoberto. 2013a. Behind Jabidah: Warlord vs. warlord. Manila Times, 21 Mar. --_. 2013b. Malaysia's masterstroke that buried our Sabah claim. Manila Times, 20 Mar. Tilman, Robert O. 1976. Sabah: Mustapha and beyond. Solidarity 10(1, Jan.-Feb.): 75-80. Tolentino, Arturo M. 1990. Voice of dissent. Quezon City: Phoenix Publishing House.

US Department of State. 1973a. Phil/Muslim conflict: GOP military assessment and urgent request for MAP aid. NARA, 9 Mar. Online, http://aad.archives.gov/aad/createpdf?ri $\mathrm{d}=8844 \& \mathrm{dt}=2472 \& \mathrm{dl}=1345$, accessed 18 Apr. 2013.

1973b. Philippine/Muslin conflict. NARA, 10 Mar. Online, http://aad.archives.gov/ aad/createpdf?rid=7983\&dt=2472\&dl=1345, accessed 18 Apr. 2013.

1973c. Phil/Muslim conflict: Marcos comments on Sabah issue NARA, 13 Mar. Online http://aad.archives.gov/aad/createpdf?rid=7607\&dt=2472\&dl=1345, accessed 18 Apr. 2013.

1973d. Philippine/Muslim conflict. NARA, 14 Mar. Online, http://aad.archives.gov/ aad/createpdf?rid=6892\&dt=2472\&dl=1345, accessed 18 Apr. 2013.

1973e. US-Philippine Mutual Defense Board Meeting (MDB) March. NARA, 15 Mar. Online, http://aad.archives.gov/aad/createpdf? $r i d=6357 \& d t=2472 \& d l=1345$, accessed 18 Apr. 2013

- - . 1973f. Muslim dissident problem in Philippines. NARA, 19 Mar. Online, http://aad. archives.gov/aad/createpdf?rid=2599\&dt=2472\&dl=1345, accessed 18 Apr. 2013.

1973g. Malaysia, Indonesia, Philippines to meet in Hong Kong. NARA, 25 May. Online, $\quad$ http://aad.archives.gov/aad/createpdf?rid=21867\&dt=2472\&dl=1345, accessed 18 Apr. 2013.

-- . 1973h. Hong Kong meeting on Sabah claim. NARA, 1 Jun. Online, http://aad. archives.gov/aad/createpdf?rid=34176\&dt=2472\&dl=1345, accessed 18 Apr. 2013.

-- - 1973i. Malik on Sabah claim. NARA, 2 Aug. Online, http://aad.archives.gov/aad/cre atepdf?rid $=50965 \& d t=2472 \& d l=1345$, accessed 18 Apr. 2013.

-- . 1973j. Muslim problems in the south. NARA, 27 Aug. Online, http://aad.archives. gov/aad/createpdf?rid=61704\&dt=2472\&dl=1345, accessed 18 Apr. 2013.

-- . 1973k. Muslim problems in the south. NARA, 27 Aug. Online, http://aad.archives. gov/aad/createpdf?rid=61744\&dt=2472\&dl=1345, accessed 18 Apr. 2013.

-- - 1974a. Moslem problems. NARA, 5 Mar. Online, http://aad.archives.gov/aad/create pdf?rid=31924\&dt=2474\&dl=1345, accessed 19 Apr. 2013.

- - 1974b. Visit of Omar al Saqqaf, Saudi Arabian minister for foreign affairs. NARA, 14 Mar. Online, http://aad.archives.gov/aad/createpdf?rid=31167\&dt=2474\&dl=1345, accessed 19 Apr. 2013

--1. 1974c. Malaysian view of southern Philippines problem. NARA, 21 Mar. Online, http://aad.archives.gov/aad/createpdf?rid=30544\&dt=2474\&dl=1345, accessed 19 Apr. 2013.

- - 1974d. Malik on Sabah dispute and Suharto's possible intermediary effort. NARA, 6 Apr. Online, http://aad.archives.gov/aad/createpdf?rid $=49542 \& d t=2474 \& d l=1345$, accessed 19 Apr. 2013

- - 1974e. New sultan of Sulu crowned: To pledge loyalty to GOP. NARA, 24 May. Online, $\quad$ http://aad.archives.gov/aad/createpdf?rid $=66044 \& d t=2474 \& d l=1345$, accessed 19 Apr. 2013.

-- . 1974f. Al Tohmamy talks with senior Philippine officials. NARA, 15 Nov. Online, http://aad.archives.gov/aad/createpdf?rid=172916\&dt=2474\&dl=1345, accessed 19 Apr. 2013.

1975a. Sabah and southern Philippines. NARA, 20 Mar. Online, http://aad.archives. gov/aad/createpdf?rid=49431\&dt=2476\&dl=1345, accessed 19 Apr. 2013.

-- - 1975b. Marcos on Sabah claim. NARA, 4 Mar. Online, http://aad.archives.gov/aad/cr eatepdf?rid=49476\&dt=2476\&dl=1345, accessed 20 Apr. 2013.

1975c. Sabah-Federal government relations. NARA, 7 Jul. Online, http://aad. archives.gov/aad/createpdf?rid=121882\&dt=2476\&dl=1345, accessed 20 Apr. 2013. 
- - . 1975d. Sabah involvement in a plot to overthrow Marcos. NARA, 18 Jul. Online, http://aad.archives.gov/aad/createpdf?rid $=121279 \& d t=2476 \& d l=1345$, accessed 20 Apr. 2013.

-- . 1976a. Marcos remarks on ASEAN. NARA, 29 Jan. Online, http://aad.archives.gov/ aad/createpdf?rid=222997\&dt=2082\&dl=1345, accessed 20 Apr. 2013.

- - 1976b. Marcos visit to Singapore. NARA, 29 Jan. Online, http://aad.archives.gov/ aad/createpdf?rid=169660\&dt=2082\&dl=1345, accessed 20 Apr. 2013.

- - . 1976c. Tatad denies GOP involvement in plot to kill Mustapha. NARA, 4 Mar. Online http://aad.archives.gov/aad/createpdf?rid $=46371 \& d t=2082 \& d l=1345$, accessed 20 Apr. 2013.

- - 1976d. Sabah claim. NARA, 5 May. Online, http://aad.archives.gov/aad/createpdf?r $\mathrm{id}=104740 \& \mathrm{dt}=2082 \& \mathrm{dl}=1345$, accessed 20 Apr. 2013.

Valmoria, C., Jr. 1981. FM defended on Sabah. Bulletin Today, 3 Dec.

Vitug, Marites D. and Glenda M. Gloria. 2000. Under the crescent moon: Rebellion in Mindanao. Quezon City: Ateneo Center for Social Policy and Public Affairs.

Weekly Nation. 1968. Sabah: From controversy to crisis. 30 Sep.

ERWIN S. FERNANDEZ was the president of the Ulupan na Pansiansiay Salitan Pangasinan (Association for the Preservation of the Pangasinan Language), and was an instructor and researcher at the Urdaneta City University. He directs his own independent research center, the Abung na Panagbasay Pangasinan (House of Pangasinan Studies). <win1tree@yahoo.com> 